\title{
ЛИТЕРАТУРА
}

1. Джелали, В.И. Об инновационной парадигме и позитивном использовании социального и личностного потенциалов// Инновации (журнал об инновационной деятельности). - С.-Петербург. - № 12 (218). - 2016.- С. 14-15.

2. Джелали, В. И., Кулиниченко, В. Л. Система физических упражнений индивидуального здраво-созидания // Вісник ХГУ ім. Каразіна. Серія Валеологія: Сучасність і майбутнє. - 2013. - №1043, вип. 15.- С.85-91.

3. Джелали, В.И., Кулиниченко В.Л. Использование системы упражнений личностной здраво-созидательной физической нагрузки в семейной медицине и валеологии (Статья 1) // Здоров я суспільства - 2014. - Т. 3 (№1,2).C. 50-63.

4. Николаева, В.В. Динамика ВКБ как показатель кризиса развития личности в условиях болезни // Психосоматика: телесность и культура/Под ред. В.В. Николаевой. - М.: Академич. Проект, 2009.

5. Фуко, М. Забота о себе. - К.: Дух и Литера, 1998. - С. 61-62.

\section{BIOETHICAL KNOWLEDGE AS CATEGORICAL NECESSITY IN THE HUMAN SURVIVAL STRATEGY}

\section{БИОЭТИЧЕСКИЕ ЗНАНИЯ КАК КАТЕГОРИЧЕСКАЯ НЕОБХОДИМОСТЬ В СТРАТЕГИИ ВЫЖИВАНИЯ ЧЕЛОВЕКА}

\author{
D. Rusnac, L. Rubanovici \\ Д. В. Руснак, Л. П. Рубанович
Nicolae Testemitanu State University of Medicine and Pharmacy, Chisinau, Republic of Moldova daniela.rusnac@usmf.md \\ Государственный медицинский и фрармацевтический университет имени \\ Николае Тестемицану, Кишинэу, Республика Молдова
}

\begin{abstract}
Nowadays it is necessary to develop a new system of values since the previous one is no longer suitable for restoring the ecosystem and the survival of humanity. Therefore, bioethics as a scientific orientation and bioethical knowledge is aimed at systemic examination of human behavior in the field of life and health sciences and comes with new solutions to overcome moral dilemmas.

В настоящее время необходимо разработать новую систему ценностей, поскольку предыдущая система больше не подходит для восстановления экосистемы и выживания человечества. Таким образом, биоэтика и биоэтические знания направлены на системное изучение поведения человека в области наук о жизни и здоровье и предлагают новые решения для преодоления моральных дилемм.
\end{abstract}

Key words: bioethics, human values, quality of life, moral dilemmas, responsibility.

Ключевые слова: биоэтика, человеческие ценности, качество жизни, моральные дилеммы, ответственность.

https://doi.org/10.46646/SAKH-2020-1-92-95

Bioethical reflection, in all areas of human activity, resides in two fundamental principles: respect for life and care for the human future. The interference of bioethics with the sphere of reason will contribute to the reorientation of human ideals, to the change of the old thinking model of socium and the transition to the new model of sustainable development, promoted by the philosophy of survival. Bioethics as a scientific direction and practical philosophy must contribute to the solution of different contemporary social-natural problems: to enable the survival of the ecosystem, to constitute a moral orientation in the socio-natural activity of Homo Sapiens, to orient the human intellect and the power of knowledge for everything capable for improving the quality of life, and overcoming all that hinders the development and manifestation of the human personality. In a constantly changing world, it is difficult to perceive the meanings and directions in which it is heading. One thing is certain: nothing influences it more than the development of human knowledge. Science is guided only by usefulness and efficiency and that is why the history of the evolution of human society has proven that it also gives rise to conflicts of consciousness. At the challenges of science and at the request of contemporaneity, which is usually placed not only outside the moral imperatives, but also frequently outside the social and legal norms, "in a world that cunning is a reward, not virtue ...", in which "Secular morality cannot offer a unique moral content, which can be rationally and compulsorily justified unambiguous way", an answer had to be found [1]. The answer was - the emergence of Bioethics, the location of which is found in the intersection of the technical sciences (especially from medicine and biology) with the humanities (philosophy, theology, law, sociology, ethics, psychology, etc.), which gives it a diversified presence.

Therefore, bioethics is defined as a scientific orientation that aims at systemic examination of human behavior in the field of life sciences and health, analyzed through the prism of moral values and requirements. If we refer to the 
etymological construction (bios + ethos), the term has a scientific charge. The ambiguity of the term bioethics is because it designates both the theoretical discourse and the practice in the field of medicine. Moral thinking in the field of bioethics uses principles, rules, rights, virtues, emotions, and paradigms to form a moral and correct attitude towards life, towards the attestation of life as a divine gift; acceptance and protection of life in all its manifestations, varieties and forms; practicing the healthy way of life; consciously ordering one's own life as its subject. The idea of the value attitude towards life is not only limited to the value of human life but goes beyond its borders, to any living breath: the life of the ocean, the life of the forest, the life of the mountains, the life of the earth, etc. Two types of problems mentioned above have attracted the attention of society, gradually leading to the awareness of responsibility towards life in general and implicitly to the emergence of bioethics as an interdisciplinary science: the ecological crisis and the scandals of human use as an instrument of science. Bioethics aims at systematic examination of human behavior in the field of life (and health), analyzed in the light of moral values and principles. The purpose of bioethics is to promote, support, and conserve life and health through the responsible commitment of the physical, mental and moral-spiritual potential of man. The role of bioethics is to present human responsibility to the various interventions on the human-society-nature system, looking at them in the light of human values and moral principles. Essentially, beyond life and death, bioethics controls and responds to everything that science and technology causes. It was considered as the most revealing manifestation of moral and social life at the end of the 20th century, and has emerged as a reaction to the interaction of three important fields: clinical medicine and medical research, philosophy and humanistic disciplines, the public health system. These spheres are in permanent interdependence, regardless of the problems that bioethics addresses.

Therefore, bioethics is a dynamic study in maintaining and creating general human values in the context of the survival of the human being. This branch of applied philosophy examines the moral problems that result from the practical application of the results of scientific research, especially in the fields of biotechnology, genetics and contemporary medicine. Philosophy has always responded to the problems of time and the problems of contemporaneity, since it could not remain unanswered, especially as they relate to the essence and human nature, to its future (in the wide sense of bioethics). Great authors, such as Aristotle, Kant, or Heidegger, have reacted to the problems of their time and, by their attitude to what has happened, they have remained in the history of humanity. Throughout the history of philosophy, representations of the essence of man were different. Thus, if the Greeks determined man's nature as rational, and man as zoon logon echon, living carrier of the logos, in the Latin translation, rational animals, then Descartes divided man into a bodily substance (res extensa) and a spiritual substance (res cogitans). The Cartesian ontological model has dominated the representations of modernity due to the development of the particular sciences. According to them, it has been noticed that the human being resembles through his corporeality the other living beings, from the chemical, physical, biological point of view, etc. Nevertheless, a part of the human being, namely its creative side, intelligence clearly differentiates it from the rest of nature. From here, another major distinction in the attempts to determine the essence of man between nature and culture. From the 19th century, the distinction is made between the sciences of nature (physics, biology, chemistry, astronomy, etc.) and the sciences of the spirit (philosophy, history, psychology, etc.). The representation of man has changed, separating him into a natural being, in a physical and biological sense, and a cultural being, in his capacity as a creator of values. These few representations exposed on the human essence make us realize the following fact: the human essence, or its specific being, cannot be exhaustively elucidated neither from the perspective of the exact sciences nor only through the contribution of cultural research. There is always an explanatory remnant, an unpredictability and an indeterminacy that makes the man impossible to classify definitively. Here, two explanations could intervene. An ontological one, after which man has a dominance since the Renaissance, from Pico della Mirandola. Accordingly to God, as supreme architect, created man without giving him anything of his own, without placing him somewhere, so that he alone could complete himself through his actions. The space in which man positions himself is between the divine and the animal world, negatively targeted. This conception combines Christian and Neoplatonic thinking, that is why the writings of Pico della Mirandola were condemned by the Church. The human boundaries, as they were themed from Aristotle to Nietzsche, are the beast and the god. The man, who misses his human, rational essence, has been compared to animals and the one who fulfills his destiny or spiritual or creative is seen as a god. The second explanation - phenomenological one, which involves the reflexive aspect of knowledge. Man, as a subject of knowledge, can transform into almost any object of the cognitive act: his nature, his corporeality, even the laws of his thinking, such as the case of the study of logic, his psychic, etc., but always remains a part that is less transparent for investigations.

Concern for the problems of bioethics in general and of medicine and biology, in particular, is a phenomenon of practical philosophy that no longer needs to be proven. These interests, however, need an interpretation, which is not sufficiently informative but must focus on the plausibility of the socio-natural system. To elucidate the point of view of philosophy in this situation, we intend to develop the following issues: the reason why philosophy, in its academic and institutional form, has to move more towards bioethical problems; philosophical representations of the essence and human nature concerning to nature; the difficulties of an "applied ethics" in the current philosophical-scientific paradigm. The 20th century was dominated by philosophical problems that resulted from the development of a particular science. The knowledge from physics, namely the theory of relativity, the new vision of the concepts of space and time, etc., have led to important philosophical debates. Besides, if the 20th century was dominated mainly by knowledge in the field of physics, mechanics, we have reason to believe that the 21 st century is under the influence of genetics, in its various forms, such as biomedicine, biotechnology, etc. Under the influence of the new results of this particular science, philosophy must 
pay attention not only to the ethical issues involved, but also to possible revisions of some major representations of the problem of knowledge, value, human creation, nature, and biosphere, etc. In the field of practical philosophy, different theories or points of view have been delimited, depending on the dominant cultural position held by either theology or anthropology or the technical sciences.

In the current evolutionary conditions, human being takes a new position in the cosmos and the biological world, and for this reason, it is necessary to develop a new system of values since the previous one is no longer suitable for restoring the ecosystem that is on the verge of a planetary homicide. The life of man would not be substantially dissimilar from the different forms of life and the natural universe with which he lives in symbiosis. Bioethics in this vision plays an important role and has the function of maintaining the evolutionary balance, the balance of the change of adaptation and the maintenance of the socio-natural system. The ethical value of any action must be analyzed both from the subjective profile of the intentionality and its objective content, as well as its consequences. The natural moral law that urges any conscience to do good and avoid evil is embodied in respect for the person, in the fullness of his values, in his ontological essence and dignity.

In our country, the bioethics field is not sufficiently promoted. It happens for at least four reasons: a) because we do not have a material and economic base capable of supporting the research in the field of genetics; b) the church tends to abrogate its promotional role less in the bioethical debates; c) the parliament, which deals with the major legislative issues, does not prioritize the legislation in the field of bioethics (we mention that in Germany, France, Switzerland, etc., the most acute ethical problems, especially the bioethical ones, are discussed in the Parliament; due to this fact, in 2002, it was forbidden cloning both in reproductive and therapeutic form, as well as the research on human embryos, egg donation for fertilization of another person, etc.); d) civil society did not pay sufficient attention to "bioproblems"; e) regrettably, some philosophers tend to stay out of metaphysical and hermeneutical problems, rejecting the field as insignificant, unimportant nowadays. As part of European culture, Republic of Moldova cannot remain outside of these debates, even if the top research in this field is not so advanced. However, we have the advantage of seeing and interpreting equidistantly the specific cultural reasons, interests, and contexts in which the debates on bioethics have different forms. The promotion of this field in Moldova is an important step in our recognition as a partner with equal value in the international context of debates on bioethical issues this contemporary moral deadlock has different ways of solving it.

Republic of Moldova is an important center for the development of knowledge in the field of bioethics, represented by the Department of Philosophy and Bioethics of the State University of Medicine and Pharmacy "Nicolae Testemitanu". Following in-depth research, the school of bioethics has found the real and efficient directions for carrying out valuable investigations regarding the implementation of bioethics in various fields of activity, especially in the scientific and didactic one. Since 1999, at the State University of Medicine and Pharmacy of the Republic of Moldova, Nicolae Testemitanu has been training students and scientific researchers in bioethics. The prodigious activity allows the development of bioethical knowledge in science, medicine and medical education.

Medical issues are only a part of the questions studied by bioethics, but their formulation and solution differ. For example, when analyzing the issue of abortion, both supporters and opponents should discuss the universal commandment "Do not kill!", but not the idea is the human embryo a human being or not. [2, p. 140-142]. Analogically, the discussions on the moral justification of organ transplantation are concentrated in the setting of the limits of human death, and not around the opinion about the sanctity (sacredness) of human life [3, p. 106]. In other words, bioethics explicitly designs its objectives: who should decide, what is and what is not allowed to do from the positions of general ethics? The problems of determining the ethical status of science, in particular biomedicine, are also present.

The interference of bioethics within the medical field in terms of ensuring the safety of life is becoming a considerable orientation in solving health problems, overcoming the current crisis in the medical system. The medical practice shows us that a doctor must possess, besides the theoretical and practical knowledge, some communication skills, to be honest, to respect the patient confidentiality, to respect the informed consent. [4, p. 125]. Therefore, the health professional must possess bioethical knowledge. In the medical field, this knowledge is necessary to make correct, rational decisions both in the training of the future specialist and in the practical medical activity. Trying to summarize the concept of responsibility, we could say that it represents the obligation to protect and promote the well-being, dignity of patients, colleagues, of society as a whole. Professional responsibility includes knowledge of the ethical and legal procedures aimed at providing services. The cognitive potential of science and especially of medicine, its innovative and transformative role of reality is elucidated in the concept developed by bioethics, which results from the new conditions of existence: the coevolution of man-society-biosphere. The current correlation of cognitive, scientific-medical and bioethical values increases the physician's responsibility towards the community and its future.

The concern of the bioethics regarding to the health also implies the assurance of a quality of life which is an inherent condition of individual and collective well-being. Health does not represent only the absence of disease or infirmity, but the state of maximum security of physical, mental and social well-being. Andrei Roth specifies that a good quality of life depends on a set of factors: favorable unpolluted environment, high standard of living, healthy food, accessible and quality industrial products, a lifestyle corresponding to the creative self-realization of the human person. [5]. Health must become the object of a permanent investigation of the balance between the field of social life, in which the difficulties of social inclusion and the forms of social exclusion coexist with the acquisition of knowledge and skills of the practical behaviors, of the spirit of solidarity. It is necessary the individual and collective involvement of medical workers in promoting health and providing qualitative medical services. The sustainable development and survival of humanity, in 
turn, is dependent on the health of those involved in ensuring the productive process and the social-cultural life. This is why in this sense we can mention that health is the "social revealer" and the central social phenomenon.

Bioethics addresses many medical dilemmas, but first of all, those that require an urgent moral solution. For this reason, bioethics must find the right place in the education and in the continuous training of the specialists in the health system. Therefore, bioethics through its principles and imperatives is a new moral form of social organization and regulation of the vital activity of the individual in relation to the biosphere. It integrates these processes and creates a new systemic conception and a new model of international collaboration for achieving the common goal - to ensure global security and survival on Earth.

\title{
REFERENCES
}

1. Engelhardt, T. H. Jr. Fundamentele bioeticii creştine /T. H. Jr. Engelhardt. - Sibiu: Deisis, 2005. - 507 p.

2. Цырдя, Т. Н. Единство феномена биоэтики и ноосферной парадигмы в стратегии обеспечения безопасности современной цивилизации / Т. Н. Цырдя. Матеріали IV Міжнародного симпозіуму з біоетики «Развитокідей біоетики у эвропейсвкому контексті» 11-12 травня 2006 р. - Київ: Сфера, 2006. - С. 140-142.

3. Astarastoae, V. Essentialia in Bioetica / V. Astarastoae, T. A. Bella. - Iaşi: Cantes, 1998. - 254 p.

4. Ţîrdea, T.N. Bioetica medicală în sănătate publică / T.N. Ţîrdea, R.C. Gramma - Chişinău: Casa editorialpoligrafică BonsOffices, 2007. - 247 p.

5. Roth, A. Modernitate şi modernizare social / A. Roth - Iaşi; Polirom, 2002. - 246 p.

\section{КОНВЕРГЕНТНЫЕ NBIC-TЕХНОЛОГИИ: ЭТИЧЕСКИЕ АСПЕКТЫ ИХ ИСПОЛЬЗОВАНИЯ В МЕДИЦИНЕ И ПРОБЛЕМЫ БИОБЕЗОПАСНОСТИ CONVERGENT NBIC-TECHNOLOGIES: ETHICAL ASPECTS OF THEIR USE IN MEDICINE AND BIOSAFETY PROBLEMS}

\author{
Е. В. Скребцова, П. Я. Смалько, Н. А.Чащин \\ K. Skrebtsova, P. Smalko, N. Chashchyn \\ ГУ «Научный центр медико-биотехнических проблем НАН Украины», г. Киев, Украина \\ biomed04@ukr.net \\ SE "Scientific Center for Medical and Biotechnical Research of NAS of Ukraine", Kiev, Ukraine
}

\begin{abstract}
Непредсказуемость последствий применения конвергентных NBIC-технологий, особенно в биомедицине, предполагает тщательный анализ вызванных ими этических проблем и поиск решений, направленных на охрану здоровья и защиту экологии человека. В статье приводятся перспективы и возможные последствия конвергенции NBIC-технологий, инструменты социального контроля, предотвращающие или снижающие риски их использования.
\end{abstract}

The unpredictability of the effects of convergent NBIC-technologies, especially in biomedicine, assumes a thorough analysis of ethical problems they cause and the search for solutions aimed at protecting health and the human environment. The article presents the prospects and possible consequences of the convergence of NBICtechnologies, tools of social control that prevent or reduce the risks of their use.

Ключевые слова: НБИК-технологии, конвергенция, потенциальные риски, социальный контроль, биомедицина, наноэтика, охрана здоровья населения.

Keywords: NBIC-technologies, convergence, potential risks, social control, biomedicine, nanoethics, public health protection.

https://doi.org/10.46646/SAKH-2020-1-95-98

Сегодня развитие науки и техники характеризуется ускоренным прогрессом в области нанотехнологий, биотехнологий, информационных технологий и когнитивных наук [1]. Все эти технологии активно взаимодействуют друг с другом, образуя так называемую NBIC-конвергенцию (N - нано; В - био; I - инфо; С - когно). Результаты комбинаций конвергированных технологий таких, например, как «нано-био», «нано-инфо», «нано-когно» приводят к социально-экономическим последствиям, которые по широте охватываемых явлений и масштабности будущих преобразований, без сомнения, можно назвать революционными [2]. Приведенные примеры с «нано-» не случайны, поскольку в концепции NBIC- конвергенции особенно важное значение имеют нанотехнологии, которые дают уникальную возможность осуществлять целенаправленные манипуляции с объектом на атомарном и молекулярном уровнях. Последние достижения в нанонауке и нанотехнологиях обуславливают быструю конвергенцию других наук и технологий. Именно поэтому нанотехнологии выступают в роли «катализатора» конвергенции. 